\title{
Economic Consideration and Model Development Spatial Trade for Sorghum and Millet Staple Food in Sudan
}

\author{
Babikir A Mohamed ${ }^{1}$, Eltighani M Elamin ${ }^{2 *}$ and Abd Elaziz A Hashim ${ }^{3}$ \\ Senior Agricultural Policies \& Capacity Development, Sudan
}

Submission: January 24, 2018; Published: March 19, 2018

"Corresponding author: Eltighani M Elamin, Senior Agricultural Policies \& Capacity Development, Sudan, Email: eltighani@yahoo.com

\begin{abstract}
This study deals with spatial trade analysis to explore the possibility of in-country inter and intra-regional trade between Southern Darfur State (SDS) and other selected States in the Greater Sudan. The productions and prices of staple food grain millet and sorghum in different States of the Sudan namely, Southern Darfur, Northern Darfur, White Nile, Southern Kordufan, Northern Kordofan, Gadaref and West Darfur, were the main concern of the analysis for the study time span 1993-2007. SDS is also highly grain trade connected to the currently independent South Sudan, where the State provides South Sudan with its whole consumption requirements from sorghum and millet. Descriptive statistic and regression analysis were used throughout the course of the study. The model of analysis used was based on Koaster [1], Correlation coefficient matrix. Regression equation was used for estimating a dependent variable from independent variables to determine the level of market co- integration among the market places covered. Trade analysis indicated that production across States is not correlated which create more opportunities for intra- regional trade between Nyala market of SDS and other States of the country for both millet and sorghum provided that trade barriers are removed.
\end{abstract}

\section{Introduction}

Trade in agricultural products serves three functions First, trade can contribute to stabilizing supply when national fluctuation in production are greater than fluctuation in the region, hence, reducing the need for holding carryover stocks. Second, it may partially substitute for working stocks if the harvesting calendar differs somewhat among trading partners. Third, trade may allow country or a region within a country to specialize in production of certain crop according to comparative advantage. Thus, trade may help to increase national income and improve food security [2].

In-country regional trade cooperation can improve food security by reducing the costs of achieving food policy objectives. Also, a group of countries or regions can achieve the same degree of food security at total lower costs.

According to the economic theory of co - integration, regional markets can only contribute less to food security than worldwide integration. In case of Greater Sudan, it can generally be presumed that the potential for intra-regional trade is greater if the country as a whole is sufficient in stable food but individual regions/states are not. To expand trade in agricultural products it is important to have these three elements: a. Internal adjustment should be directed towards internal and external agricultural trade regimes and exchange rate policy.

b. External adjustment should be directed towards reorientation in food policy.

c. Food aid in the region must be considered as a disincentive for intra-regional trade.

\section{Framework of analysis}

The study deals with spatial trade analysis to explore the possibility of in-country inter and intra- regional trade between SDS and other selected States in Greater Sudan (before South Sudan Independence). The productions and prices of millet and sorghum in different States of the Sudan namely, Southern Darfur, Northern Darfur, White Nile, Southern Kordufan, Northern Kordofan, Gadaref and West Darfur, were the main States of concern of the analysis for the study time span 19932007 [3-12].

Descriptive statistic and regression analysis were used throughout the course of the study. The model of analysis used was based on Koaster (1985), Correlation coefficient matrix. 
Regression equations were used for estimating a dependent variable from independent variables. In the case of this study time $t$ is the dependable variable and production $q$ and market price $\mathrm{p}$ is the independent variables. In functional notation this is sometimes written as:

$$
t=f(q 1, q 2, q 3, \ldots q n)(1),
$$

Where $\mathrm{t}$, is the time and $\mathrm{q} 1, \mathrm{q} 2, \mathrm{q} 3$...qn are the quantities of grain.

For the price the equation is written as:

$$
t=f(p 1, p 2, p 3, \ldots . p n)(2),
$$

Where $t$, is the time and $\mathrm{p} 1, \mathrm{p} 2, \mathrm{p} 3 \ldots$ pn are the prices of grain.

Regression analysis describes the effect of one or more variables (designed as independent variables) on a single (designed as the dependent variable) by expressing the latter as a function of the former.

Correlation analysis, on the other hand, is an index for measuring the degree of association, fluctuation, estimating and testing significance between the variables. Coefficient of Variation (CV) is used to measure fluctuation in production and prices. It is noted that an index value of 100 shows that the production pattern of two States are completely alike (that is the price in one state is perfectly correlated/co-integrated with the other state) whereas zero index implies complete dissimilar price pattern.

According to the economic theory of integration, regions differ in their production and market patterns have greater potential for expanding intra-regional trade if barriers are removed. Also, regional interstate trade can only contribute to food security if regions/states are not similar in their production and trade pattern, that their correlation coefficients are not similar.

\section{Spatial trade analysis}

Trade analysis using Table 1, has showed that millet production has become far less covariant and correlation was small and insignificant between all the States and Nyala or SDS, has the chance of regional trade between all the States except for Elobeid and Elfashir. Individual States are denoted by their capital cities, Gedarif or Gedarif State, Elobeid for North Kordofan, Damzin for Blue Nile, Kosti for White Nile, Nyala for

\begin{tabular}{|c|c|c|c|c|c|c|}
\hline & Gedarif & Elobeid & Damazin & Kosti & Nyala & Elfashir \\
\hline Gedarif & 1 & 0.013 & 0.305 & 0.07 & 0.126 & -0.052 \\
\hline Elobeid & 0.013 & 1 & 0.263 & $0.976^{* *}$ & 0.237 & -0.014 \\
\hline Damazin & 0.305 & 0.263 & 1 & 0.281 & $-0.478^{*}$ & -0.249 \\
\hline Kosti & 0.07 & $0.976^{* *}$ & 0.281 & 1 & 0.242 & -0.089 \\
\hline Nyala & 0.126 & 0.237 & $-0.478^{*}$ & 0.242 & 1 & 0.459* \\
\hline Elfashir & -0.052 & -0.014 & -0.249 & -0.089 & $0.459^{*}$ & 1 \\
\hline
\end{tabular}
South Darfur, and Elashir or North Darfur State.

Source: Computed from secondary data of the study.

${ }^{* *}$ Correlation is significant at the 0.01 level (1-tailed)

${ }^{*}$ Correlation is significant at the 0.05 level (1-tailed)

Sorghum production in the States has become far less covariant; correlation was small and insignificant between Kosti and Gedarif, Damazin and Gedarif, Elfashir and Elobeid, and Damazin and Kosti. Nyala has the chance of regional trade since correlation coefficient on production was small, positive, and statistically insignificant and correlation of prices was large,

positive, and highly significant with each of the other five state regional markets (Table 2).

Trade analysis has also indicated that production across States is not correlated which create more opportunities for regional trade between Nyala and other five States of the country for both millet and sorghum (Tables 1-4).

Table 2: Correlation coefficient of reported millet prices among selected States of Sudan, 1993-2006

\begin{tabular}{|c|c|c|c|c|c|c|}
\hline & Gedarif & Elobeid & Damazin & Kosti & Nyala & Elfashir \\
\hline Gedarif & $0.699^{* *}$ & $0.938^{* *}$ & $0.979^{* *}$ & $0.714^{* *}$ & $0.781^{* *}$ & $0.916^{* *}$ \\
\hline Elobeid & $0.699^{* *}$ & $0.801^{* *}$ & $0.678^{* *}$ & $0.797^{* *}$ & $0.853^{* *}$ & $0.714^{* *}$ \\
\hline Damazin & $0.938^{* *}$ & $0.801^{* *}$ & $0.953^{* *}$ & $0.757^{* *}$ & $0.775^{* *}$ \\
\hline Kosti & $0.979^{* *}$ & $0.678^{* *}$ & $0.935^{* *}$ & & $0.840^{* *}$ \\
\hline Nyala & $0.714^{* *}$ & $0.797^{* *}$ & $0.757^{* *}$ & $0.714^{* *}$ & $0.840^{* *}$ & 1 \\
\hline Elfashir & $0.781^{* *}$ & $0.916^{* *}$ & $0.853^{* *}$ & $0.775^{* *}$ & 0.2 \\
\hline
\end{tabular}

Source: Computed from secondary data of the study.

${ }^{* *}$ Correlation is significant at the 0.01 level (1-tailed)

${ }^{*}$ Correlation is significant at the 0.05 level (1-tailed) 


\section{Agricultural Research \& Technology: Open Access Journal}

Table 3: Correlation coefficient of reported sorghum production among selectedStates of Sudan, 1993-2006.

\begin{tabular}{|c|c|c|c|c|c|c|}
\hline & Gedarif & Elobeid & Damazin & Kosti & Nyala & Elfashir \\
\hline Gedarif & & -0.323 & 0.37 & 0.561 & 0.134 & 0.137 \\
\hline Elobeid & -0.323 & & 0.111 & 0.163 & 0.195 & 0.407 \\
\hline Damazin & 0.37 & 0.111 & & 0.431 & 0.189 & -0.189 \\
\hline Kosti & $0.561^{*}$ & 0.163 & 0.431 & & 0.131 & -0.086 \\
\hline Nyala & 0.134 & 0.195 & 0.189 & 0.131 & 0.072 \\
\hline Elfashir & 0.137 & 0.407 & -0.189 & -0.086 & 0.072 & 1 \\
\hline
\end{tabular}

Source: Computed from secondary data of the study

${ }^{* *}$ Correlation is significant at the 0.01 level (1-tailed)

${ }^{*}$ Correlation is significant at the 0.05 level (1-tailed)

Table 4: Correlation coefficient of reported sorghum prices among selected States of Sudan, 1993-2006.

\begin{tabular}{|c|c|c|c|c|c|c|}
\hline & Gedarif & Elobeid & Damazin & Kosti & Nyala & Elfashir \\
\hline Gedarif & & $0.989^{* *}$ & $0.958^{* *}$ & $0.984^{* *}$ & $0.984^{* *}$ & $0.861^{* *}$ \\
\hline Elobeid & $0.989^{* *}$ & & $0.955^{* *}$ & $0.984^{* *}$ & $0.806^{* *}$ & $0.880^{* *}$ \\
\hline Damazin & $0.958^{* *}$ & $0.955^{* *}$ & & $0.938^{* *}$ & $0.876^{* *}$ & $0.912^{* *}$ \\
\hline Kosti & $0.984^{* *}$ & $0.984^{* *}$ & $0.938^{* *}$ & & $0.809^{* *}$ & $0.884^{* *}$ \\
\hline Nyala & $0.736^{* *}$ & $0.806^{* *}$ & $0.876^{* *}$ & $0.809^{* *}$ & & $0.812^{* *}$ \\
\hline Elfashir & $0.861^{* *}$ & $0.880^{* *}$ & $0.912^{* *}$ & $0.884^{* *}$ & $0.812^{* *}$ & 1 \\
\hline
\end{tabular}

Source: Computed from secondary data of the study

${ }^{* *}$ Correlation is significant at the 0.01 level (1-tailed)

${ }^{*}$ Correlation is significant at the 0.05 level (1-tailed)

Results and Discussion

\section{Market association}

Per capita grain production showed downward trend in all of the selected States of the country except for slight upward trend in Elobeid and Kosti. With respect to per capita grain balance, Gadarif showed the best situation followed by Damazin and Kosti. Elobeid, Nyala and Elfashir reported the worst situation from 1993 to 2006 (Table 5).

Table 5: Per capita grain balances* among selected States of Greater Sudan, 1993-2006 in tones???????

\begin{tabular}{|c|c|c|c|c|c|c|}
\hline Year & Gedarif & ElObied & Damazin & Kosti & Nyala & Elfashir \\
\hline 1993 & 575 & -120 & 111 & 64 & -29 & -108 \\
\hline 1994 & 679 & 35 & 164 & 129 & 73 & 17 \\
\hline 1995 & 359 & -132 & 203 & 78 & -16 & -133 \\
\hline 1996 & 839 & -112 & 270 & 148 & -16 & -126 \\
\hline 1997 & 617 & -114 & 370 & 130 & -16 & -84 \\
\hline 1998 & 778 & -108 & 144 & 153 & 53 & 49 \\
\hline 1999 & 135 & -112 & -49 & 29 & -29 & -86 \\
\hline 2000 & 272 & -118 & 18 & -131 & 18 & -98 \\
\hline 2001 & 207 & -63 & 274 & -17 & 3 & -97 \\
\hline 2002 & 206 & -87 & -1 & 28 & 19 & -91 \\
\hline 2003 & 431 & -53 & 98 & 211 & -15 & -90 \\
\hline 2004 & 76 & -119 & 38 & -49 & -73 & -97 \\
\hline 2005 & 319 & 798 & 221 & 188 & -15 & -99 \\
\hline 2006 & 183 & 38 & 258 & 168 & -27 & -124 \\
\hline
\end{tabular}

Source: Computed from secondary data of the study

*Per capita grain balance is the share of the person from the balance of grain production and consumption of the State.

*Per capita grain production balance is the share of the person of grain production of the State. 
The prices of millet and sorghum showed upward trends in all selected State markets of the country. Although all millet prices correlation coefficients reported large, positive and highly statistically significant, production of millet showed the small, positive and insignificant correlation coefficients which indicate that there is a chance for trade between Southern Darfur and other five States. Accordingly, higher grain prices are likely to increase the importance of regional trade in stable food crops between Southern Darfur and the selected States (Figure 1).

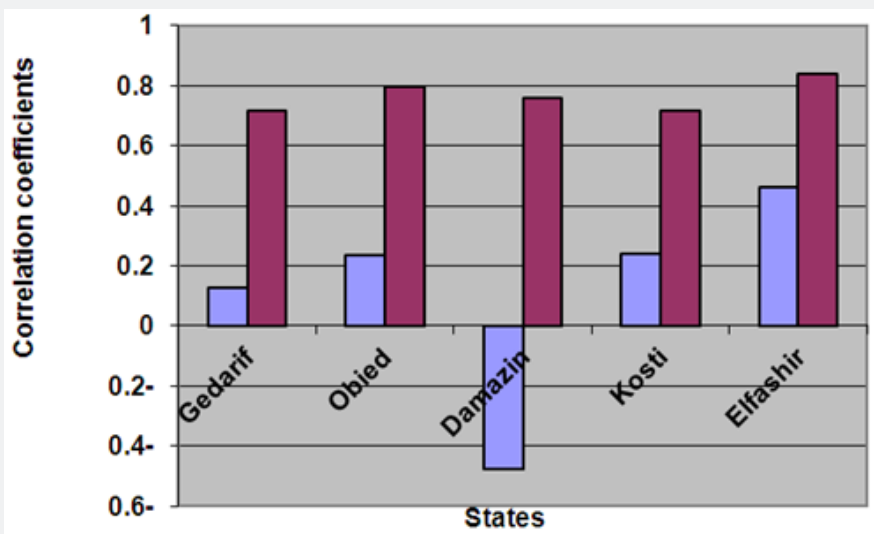

口Production

口Price

Figure 1: Southren Darfur millet market association.

With respect to sorghum prices, all the States showed upward trends, large, positive and highly statistically significant correlation coefficients but the production showed small, positive and insignificant correlation coefficients which indicate that there is a chance for trade to operate between these States and Southern Darfur (Figure 2).

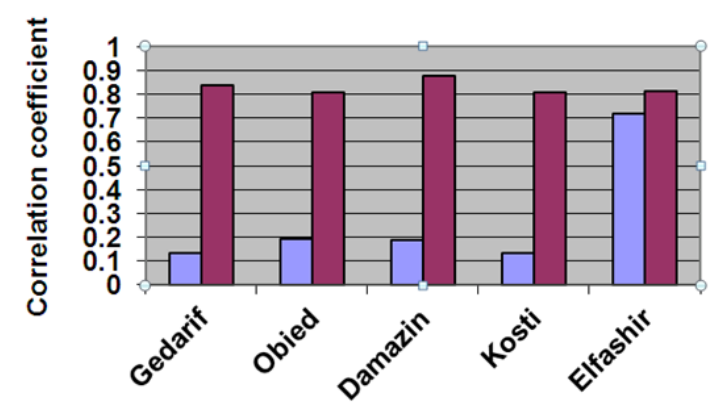

口Production

$\square$ Price

States

Figure 2: Southren Darfur sorghum market association.

\section{Per capita grain production balances}

The result of per capita grain production showed downward trend in all of the selected in-country States except for slight upward trend in Elobeid and Kosti. With respect to per capita grain balance, Gadarif showed the best situation followed by Damazin and Kosti. The worst situation was reported inNyala and Elfashir

The results of the analysis showed that millet and sorghum production has become far less covariant and correlation was small and insignificant and the grain prices are high which likely to increase the importance of regional trade in stable food crops between Southern Darfur and each of the other selected States.

\section{Conclusion and Policy Implication}

All the results of the analysis of per capita grain production, per capita grain balance and the production across States is not correlated, indicating a high policy option or increased opportunities for regional trade between Nyala and other States of the Greater Sudan for both millet and sorghum provided that trade barriers are removed.

\section{References}

1. Koaster Ulrich (1986) Region Cooperation to Improve Food Security in Southern and Eastern African Countries. Research Report No. 53, International Food Policy Research Institute, Washington, USA.

2. Koaster Ulrich (1983) Policy Option for the Grain Economyof the European Community: Implication for Developing Countries. Research Report No. 35, International Food Policy Research Institute, Washington, USA.

3. State Ministry of Agriculture (1997-2005) Post-Harvest Assessment, Southern Darfur State, Sudan.

4. State Ministry of Agriculture (1993-2006) Post-Harvest Assessment, Southern Darfur State, Sudan.

5. State Ministry of Agriculture (1993-2006) Post-Harvest Assessment, Northern Darfur State, Sudan. 
6. State Ministry of Agriculture (1993-2006) Post-Harvest Assessment, West Darfur State, Sudan.

7. State Ministry of Agriculture (1993-2006) Post-Harvest Assessment, White Nile State, Sudan.

8. State Ministry of Agriculture (1993-2006) Post-Harvest Assessment, Blue Nile State, Sudan.

9. State Ministry of Agriculture (1993-2006) Post-Harvest Assessment, Southern Kordufan State, Sudan.
10. State Ministry of Agriculture (1993-2006) Post-Harvest Assessment, Northern Kordufan State, Sudan.

11. State Ministry of Agriculture (1993-2006) Post-Harvest Assessment, Gadaref State, Sudan.

12. Western Savannah Development Corporation (1986-1996) PostHarvest Assessment, Southern Darfur State, Sudan. 